JACOB ONGAKI

\title{
An examination \\ of the relationship \\ between flexible \\ work arrangements, \\ work-family conflict, organizational \\ commitment, and job \\ performance
}

Jacob Ongaki, Ph.D., Assistant Professor of Business Colorado, Mesa University, USA, ORCID: 0000-0002-3174-813X.

\section{Introduction}

The changes in workforce demographics particularly increase in dual-earner families, and single-parents, have resulted in increased multiple role conflicts of work and the family. The work-family conflict comprises incompatible roles due to the fixed resources for a person between work and family domains which are often problematic (Blazovich, Smith \& Smith, 2013; Galinsky \& Matos, 2011). The Society for Human Resource Management or SHRM (2016) indicated $46 \%$ of male and $43 \%$ of women professional workers experienced work-family conflict related to work and family role demands which was similar the 2008 survey by the National Study of Changing (Galinsky \& Matos, 2011) and others by Nielsen and Harris along with Pew Research (Parker \& Wang, 2013; ShannonMissal, 2014). The management support of flexible work arrangement declined from 31\% to $14 \%$ between 2005 and 2016. The predicted exponential growth within the service sector 
(Coenen \& Kok, 2014; World Bank, n.d) has warranted an investigation. Employees' increased role demands and uncertain working schedules and limited resources (such as time) that are often problematic (Coenen \& Kok, 2014; Henly \& Lambert, 2014). The concept of schedule could mitigate employees' inter-role conflicts (Allen, Johnson, Kiburz, \& Shockley, 2013). The unmanaged employees' issues and concerns present organizational challenges such as organizational commitments and job performance in the United States (De Janasz et al., 2013) that necessitated this investigation. The purpose of this quantitative, non-experimental study was to determine the effects of employees' use of flexible work arrangements (such as a flexible work schedule and telecommute), with relation to work-family conflict and family-work conflict (as covariates), and organizational outcomes such as organizational commitment and job performance (as dependent variables) for employees in the state of Texas, United States based on self-reported sample population.

The United States (US) workforce demographics have changed and grown steadily over the last few decades as a result of a growing number of female workers, divorced workers, and members of the Generations X and Y (Minnotte, 2012). The family structures have changed since the mid-1980s resulted in increased employees' responsibilities toward work and family (Galea, Houkes, \& De Rijk, 2014). The role demand may affect employees' work performance (Cheung \& Wong, 2013). In 2012, Human Resource Management ranked the workplace flexibility benefits of organizations as the highest in priority besides job compensation and career opportunities for job seekers (Cairns, 2013). Fortune magazine reported that $82 \%$ of the best 100 companies offered employees the option to work at least $20 \%$ of the time remotely.

Failure to recognize the work-family conflict issue may harm organizational outcomes such as employees' organizational commitment (Caykoylu, Egri, Havlovic, \& Bradley, 2011) and job performance (Bal et al., 2012; Blazovich, Smith, \& Smith, 2013). The telecommuting and variable work schedules remain the most favored forms of flexible work arrangement practices in many organizations nationwide (Wells-Lepley, Thelen, \& Swanberg, 2015) and for new hires (SHRM, 2013). The options are negatively related to work-family conflict and familywork conflict (De Sivatte \& Guadamillas, 2013; Duncan \& Pettigrew, 2012; Thompson, Beauvais, \& Lyness, 1999). Reduced levels of work-family conflict among employees may decrease negative effects and may improve employees' work productivity (Blazovich et al., 2013; Carlson et al., 2014) in which an organization can leverage its competitiveness in a global economy (Fiksenbaum, 2013; Maharshi \& Chaturvedi, 2015). 
The respondents' self-administered and self-reported data was collected online/web survey (via Qualtrics) without manipulation based on previously published instruments. The questionnaire survey was limited to a sample of employees with flexible work arrangement experience to gather their opinions or perceptions about the program concerning covariate and dependent variables. The parametric assumption violation of normality created doubt or authenticity of the ANCOVA findings. This warranted further analysis to include KruskalWallis analysis for non-parametric data analysis with fewer restriction assumptions regarding non-normally distributed data.

\section{Literature review}

A modern full-time employee expected to work long hours (Munsch, Ridgeway, \& Williams, 2014) has been unwilling to sacrifice personal values for good pay and their jobs (Chernyak-Hai \& TzinerNetanya, 2015). Despite a high acceptance level of flexible work arrangement practices by certain workers, the programs are out of reach to many workers in various organizations (Sweet et al., 2014). Flexible work options provide leverages to manage work and life roles more effectively (Wickramasinghe, 2012). The options provide employees to manage their work such as to work later in the day, discretion on start or end times or work remotely (telecommuting) without compromising performance. Sturman and Walsh (2014) examined the relationships of employees' working hours with fit and organizational support, job stress, work-family conflict, and turnover intentions. The results revealed that the majority of workers worked 13 extra hours per week which is a relevant concern to many workers in the United States Organizational support and employers attentive to workers' needs may induce positive feelings, behaviors, and attitudes in the workplace which could result in a long-lasting relationship of reduced negative organizational outcomes (such as increased organizational commitment and job performance). This quantitative longitudinal study included 2,571 respondents from various professions in the first wave of data collection and 1,665 in the second survey which was administered online.

Based on a study that utilized both qualitative (focus study group) and quantitative (field data analysis) investigation methods, work-family conflict issues correlate negatively toward work attitudes. The sample population included 48 graduate students from a public university of Naples in Southern Italy who engaged in a roundtable discussion. The lack of organizational mechanisms to assist workers to manage work and personal life may lead 
to lower morale and result in consequences such as decreased employees' organizational commitment (Buonocore, Russo, \& Ferrara, 2015). The study aimed to investigate workers' of various generations (baby boomers, Gen Xers, and Millennials) in Italy and their perceptions about work-family conflict. The findings revealed that generational workers were not correlated to the work-family conflict with organizational commitment. The use of flexible work arrangements may be successful when explicitly stated in the company policy and supported by managers (Gözükara \& Çolakoğlu, 2015). Telecommuting trended up 34\% and 66\% in 2005 and 2016 with small companies likely to offer workplace flexibility (SHRM, 2016). The American Psychological Association (2011) sponsored a study showed that only $36 \%$ of United States workers were satisfied with the employer offered work-family balance programs (Kossek, Baltes, Matthews, 2011). Another survey included private and public faculty members in Punjab, Pakistan indicated a positive association between flexible work arrangement practices and organizational outcomes (Galea et al., 2014). This qualitative interview of 15 employees indicated that flexible work arrangements are fundamental for employees to balance multiple roles related to work and family. Conversely, Bhave, Kramer, and Glomb (2013) found a negative relationship between employees' satisfaction with organizational benefits (such as medical health insurance and pay) and work-family conflict. A qualitative case study investigation by Atkinson and Hall (2011) about the effects of flexible work arrangements revealed that employees were satisfied with the practices and increased their wellbeing. Another study by De Sivatte and Guadamillas (2013) explored the impact of employees' use and implementation of flexible work arrangements on organizational outcomes. The survey included 480 responses from many private organizations in Spain where flexible work arrangement practices were available. These results were similar to Goh, Ilies, and Wilson (2015), and Gözükara and Çolakoğlu (2015) which concluded that informal rather than formal practices were more effective in reducing work-family conflict (Goh et al., 2015). The work-family conflict has gotten the attention of public, national, and organizational leaders due to its prevalence (Burke, Koyuncu, \& Fiksenbaum, 2013; Brown, 2010). This was two-year quantitative research of 12,095 sample population experienced several work-related demands, shift work, job insecurity, and other work and family-related challenges. The study revealed that work-family conflict and other factors were related to employees> work performance. 


\section{Research Method and Design}

The non-experimental quantitative research design was used to investigate work-family conflict as a real issue in operation and management to test role theoretical knowledge and to determine the study objectivity based on statistical data analysis (Quick \& Hall, 2015c). The study design provided insight into the understanding of variable interaction and inferential statistical analyses and interpretations (Zikmund, Babin, Carr, \& Griffin, 2010).

The variables (constructs) for the study included flexible working arrangements (flextime and telecommuting practices) categorical dummy predictor variable, work-family conflict and family-work conflict as covariates, and organizational commitment and job performance as outcome variables or dependent variables.

The white-collar employees' demographic characteristics included age, gender, education, income, rank, race, and job classification or tenure information valuable to determine further variable relationships. The respondents' selfadministered and self-reported data were primarily collected online/web survey (via Qualtrics software) without manipulation based on previously published instrument questionnaire. The questionnaire survey was limited to a sample of employees with flexible work arrangement experience to gather their opinions, attitudes, or perceptions about the program with predictor, covariates, and dependent variables. The survey participants were primarily recruited through permission in organizations and institutions and the researcher's networks. The snowballing technique was used as a secondary or complementary recruitment technique. The identified sample was requested to forward the email/text message and the link to potential participants through their social networks (snowballing). The ANCOVA and Kruskal-Wallis research techniques were used given the nature of the survey data complexity and assumption.

A survey of self-reported responses was sent to 360 to primarily two potential institutions in Dallas/Fort Worth and Arlington Texas. The purposive sampling survey used employees with flexible work arrangements experience and geographical restrictions. A minimum of 115 participants was required based on the number of independent and dependent variables in the study $\left(\mathrm{G}^{*}\right.$ power tool), $95 \%$ confidence interval ( 0.05 alpha two-tailed test). The response rate was about $50 \%$. The respondents for the study included 237 workers with formal and/or informal flexible work arrangement practices, such as flexible schedules and telecommuting options. A total of 21 responses were not usable due to incomplete critical data to the study. 
The questionnaire survey enabled the researcher to collect raw data on flexible work arrangements and workers' beliefs, attitudes, and emotions about their organizational commitment and work performance. The 25 survey questions were structured, specific, and narrowed to minimize general phenomenon by assigning measurable values related to specific constructs and scales. Each question was linked directly to a specific construct and instrument scale to analyze the variables' association strengths. The questionnaire questions were chosen from various previously published instruments to measure employees' perceptions and feelings about the study variables. The instruments used to create the questions included flexible work arrangement practices (Thompson et al., 1999; Swanberg et al., 2011), work-family conflict (Matthews et al., 2010), organizational commitment (Halverson et al., 2004), and job performance (Yang et al., 2009). The categorical measures included flexible work schedule/ flextime coded as 1, telecommuting as 2, and the use of both flexible schedule and telecommuting as 3 (Thompson et al., 1999) Likert-type scale. Also, the respondents indicated they preferred the type of flexible work arrangement used within the last five years.

The work-family conflict and family-work conflict instrument were used to assess employee inter-role conflict as a result of fixed resources related to demands, time constraints, and strain associated with work and personal responsibilities (Matthews et al., 2010) Likert-type scale. The organizational environment attitude scale and instrument were originally developed by Mowday, Steers, and Porter (1979) and modified by Halverson et al. (2000) to investigate organizational commitment (Halverson et al., 2004) Likerttype scale. The job performance measure and instrument were developed to measure employees' organizational roles in a manufacturing context with a Cronbach's coefficient alpha of .93 (Yang et al., 2009). The sum score questions for each instrument were averaged to produce a variable measure of Likert-type scale.

The researcher obtained permission to use or modify selected parts of these previously published instruments for the research study. The study variables were interval variables within the survey measured through Likerttype interval scales (Table 1). For each construct item, the lowest score meant less agreement to the statement and the highest score translated to complete agreement with the statement. The survey items were tabulated to reflect the participants' responses and to evaluate the variable relationships regarding the use of flexible work arrangements and work-family conflict on organizational outcomes. 
Table 1. Summary of variable operationalization

\begin{tabular}{l|l|l|l|l}
\hline Variable & Original Source & $\begin{array}{l}\text { Scaling } \\
\text { Method }\end{array}$ & $\begin{array}{l}\text { Points } \\
\text { Scale }\end{array}$ & Likert-type Scale \\
\hline $\begin{array}{l}\text { Flexible-work arrange- } \\
\text { ments }\end{array}$ & $\begin{array}{l}\text { Thompson et al. } \\
(1999)\end{array}$ & Nominal & 3-Point & $\begin{array}{l}\text { Flextime (1) Telecommuting } \\
(2) \text { Both (3) }\end{array}$ \\
\hline Work-family conflict & $\begin{array}{l}\text { Matthews et al. } \\
(2010)\end{array}$ & Interval & 5-Point & $\begin{array}{l}\text { strongly disagree (1) to } \\
\text { strongly agree (5) }\end{array}$ \\
\hline Family-Work conflict & $\begin{array}{l}\text { Matthews et al. } \\
(2010)\end{array}$ & Interval & 5-Point & $\begin{array}{l}\text { Strongly disagree (1) Strong- } \\
\text { ly agree (5) }\end{array}$ \\
\hline Job performance & $\begin{array}{l}\text { Yang et al. (2009) } \\
\text { Interval }\end{array}$ & 5-Point & $\begin{array}{l}\text { strongly disagree (1) to } \\
\text { strongly agree (5) }\end{array}$ \\
\hline $\begin{array}{l}\text { Organizational commit- } \\
\text { ments }\end{array}$ & $\begin{array}{l}\text { Halverson et al. } \\
(2004)\end{array}$ & Interval & 7-Point & $\begin{array}{l}\text { Strongly disagree (1) Strong- } \\
\text { ly agree (7) }\end{array}$ \\
\hline
\end{tabular}

Source: own study

\section{Data analysis}

The Qualtrics web-based software enabled the extraction of data in SPV format uploaded in SPSS for data analyses. The survey was comprised of six sections starting with demographic information followed by the study questionnaire. Data were analyzed using the SPSS data computations statistical methods for testing predictor and outcome variable relationships using ANCOVA and Kruskal-Wallis coefficient. Other SPSS statistical outputs including descriptive types (such as mean, median, mode, and standard deviation data) were used to assess variable relationships. The visual inspection of assumptions such as histograms, probability plots, and scatter plots were assessed to determine patterns, shapes, trends, and relationships. The descriptive statistics drawn from the sample population included the selection of the mean, standard deviations, and other statistical outputs that were selected and used to evaluate the study results. The validity was evaluated based on specific instruments and previous studies.

The study covariate variables were measured on an interval scale, the relationship assumption between the dependent variable and each level of the independent variable. The Kolmogorov-Smirnov and Shapiro-Wilks normality tests were significant $(\mathrm{P}<.05)$ for job performance suggesting that data was 
not normally distributed per ANCOVA validation assumptions (independent variables vs dependent variables). However, the result for organizational commitment was non-significant or $\mathrm{P}>.05$ that data were normally distributed. The inconclusive data normality test resulted in employing Kruskal-Wallis which doesn't require normality assumption. Therefore, two techniques the ANCOVA for a parametric and Kruskal-Wallis for non-parametric datasets were utilized for this study. There are several assumptions for using ANCOVA that the covariate has to be at least approximately continuous, the relationship between the dependent variable and the covariate has to be linear within each level of the independent variable, variance homogeneity and normal distribution within each level of the independent variable.

The make-up of employees' use of flexible work schedules represented 97 (40.9\%), 37 (15.6\%) comprised of telecommuters, and approximately 103 (43.5\%) utilized both flexible work schedules and telecommuting in their organization. The survey demographics showed respondents were 133 males and 104 females and 138 married employees with children under 18 years old. Employees included 111 with a bachelor's degree and 84 with a master's degree and higher. About $45 \%$ of employees worked in the firm for more than 3 years and $60.3 \%$ of employees came from a family with two and more income earners.

The outliers were within \pm 3 in the data range and no extreme outliers outside the mean range and standard deviation. Therefore, there were no cases with standardized residuals and extreme outliers. The skewness and kurtosis are valid and robust measures for normally distributed data (Field, 2013). The skewness or the kurtosis values were less than one for the dependent variables which were an indication of fairly distributed data for parametric analysis. Therefore, the visual inspection, skewness, and kurtosis suggest that the study data met the minimum data distribution requirement. The Levene's test was not statistically significant data assumption of the equality of variances $P>.05$ (see Table 4) for job performance and work-family conflict and family-work conflict as covariates (at each level). Conversely, the result was statistically significant for organizational commitment or P<.05 (see Table 4) and work-family conflict and family-work conflict as covariates (at each level-a violation of equality of variance ANCOVA assumption). The interaction between FWAs and covariates work-family conflict and family-work conflict (test of between-subjects effects) was not statistically significant meeting ANCOVA homogeneity assumption $(P>.05)$ as shown in table 5. The Durbin-Watson test was 1.87 which confirmed no autocorrelation of residuals among predictor and outcome variables (Greene, 2012). The values were within the acceptable range of critical values. The 
Durbin-Watson confirmed lack of type II error implies a failure to reject the null hypothesis $\left(\mathrm{H}_{0}\right)$ when it is false and vice versa to type I error.

Table 2. Leven's tests

\begin{tabular}{c|c|c}
\hline \multicolumn{1}{c|}{ Covariate } & Job performance & Organizational commitment \\
\hline Work-family conflict & 0.28 & 0.00 \\
\hline Family-work conflict & 0.34 & 0.00 \\
\hline
\end{tabular}

Source: own study

Table 3: Homogeneity

\begin{tabular}{l|c|c}
\hline \multicolumn{1}{c|}{ Dependent variable } & $\begin{array}{c}\text { Flexible work } \\
\text { arrangement*work-family } \\
\text { conflict (Sig.) }\end{array}$ & $\begin{array}{c}\text { Flexible work } \\
\text { arrangement }\end{array}$ \\
conflict (Sig.)
\end{tabular}

Source: own study

The Kolmogorov-Smirnov and Shapiro-Wilk tests for data normality assumptions were significant of alpha $\mathrm{P}<.05$. This was an indication of data deviation from ANCOVA normality assumption for each level of FWAs and job performance. However, the relationship for each level of FWAs and organizational commitment was not statistically significant (P>.05), an indication of normally distributed data as shown in table 2 . The variable data transformations were performed to normalize data to fit parametric analysis. The methods of data transformation included the logarithm method for a family-family conflict data (Greene, 2012). The job performance variable failed normalization data transformation. The P-P plots, Q-Q plots, and histograms were visually inspected. The visual graphs showed a fairly distributed data except for job performance variable. The scatter plots were inconclusive for ANCOVA linearity relationship assumptions. However, the data transformation helped to reduce skewness and kurtosis to less than 1 (table 3). Because of the complex data not meeting normality test or inconclusive assumption, the researcher further employed Kruskal-Wallis test analysis 
(which does not require normally distributed data) to confirm the rigorous nature of the study.

Table 4. Tests of normality

\begin{tabular}{|c|c|c|c|c|c|c|c|}
\hline \multirow{2}{*}{ DV } & \multirow{2}{*}{$\begin{array}{l}\text { Flexible work } \\
\text { arrangements }\end{array}$} & \multicolumn{3}{|c|}{ Kolmogorov-Smirnov } & \multicolumn{3}{|c|}{ Shapiro-Wilk } \\
\hline & & Statistic & df & Sig. & Statistic & df & Sig. \\
\hline \multirow{3}{*}{$\begin{array}{l}\text { Work-family } \\
\text { conflict }\end{array}$} & Flexible schedule & .11 & 97 & .00 & .96 & 97 & .01 \\
\hline & Telecommuting & .14 & 37 & .08 & .95 & 37 & .12 \\
\hline & $\begin{array}{l}\text { Flexible schedule \& Tele- } \\
\text { commuting }\end{array}$ & .10 & 103 & .01 & .97 & 103 & .01 \\
\hline \multirow{3}{*}{$\begin{array}{l}\text { Family-work } \\
\text { conflict }\end{array}$} & Flexible schedule & .16 & 97 & .00 & .95 & 97 & .00 \\
\hline & Telecommuting & .21 & 37 & .00 & .91 & 37 & .00 \\
\hline & $\begin{array}{l}\text { Flexible schedule \& Tele- } \\
\text { commuting }\end{array}$ & .16 & 103 & .00 & .95 & 103 & .00 \\
\hline \multirow[t]{3}{*}{ Job performance } & Flexible schedule & .24 & 97 & .00 & .89 & 97 & .00 \\
\hline & Telecommuting & .32 & 37 & .00 & .79 & 37 & .00 \\
\hline & $\begin{array}{l}\text { Flexible schedule \& Tele- } \\
\text { commuting }\end{array}$ & .30 & 103 & .00 & .84 & 103 & .00 \\
\hline \multirow{3}{*}{$\begin{array}{l}\text { Organizational } \\
\text { commitment }\end{array}$} & Flexible schedule & .13 & 97 & .20 & .91 & 97 & .40 \\
\hline & Telecommuting & .13 & 37 & .17 & .94 & 37 & .38 \\
\hline & $\begin{array}{l}\text { Flexible schedule \& Tele- } \\
\text { commuting }\end{array}$ & .12 & 103 & .08 & .92 & 103 & .46 \\
\hline
\end{tabular}

Table 5. Study Descriptive Analysis (Untransformed)

\begin{tabular}{l|c|c|c|c}
\hline Category & $\begin{array}{c}\text { Work-family } \\
\text { conflict }\end{array}$ & $\begin{array}{c}\text { Family-work } \\
\text { conflict }\end{array}$ & $\begin{array}{c}\text { Job perfor- } \\
\text { mance }\end{array}$ & $\begin{array}{c}\text { Organizational } \\
\text { commitment }\end{array}$ \\
\hline Mean & 2.85 & 2.3 & 4.5 & 4.45 \\
\hline Std. Deviation & 0.1 & 0.86 & 1 & 1.69
\end{tabular}




\begin{tabular}{l|l|l|l|l}
\hline Skewness & 0.3 & 0.58 & -1.88 & -0.43 \\
\hline Std. Error of Skewness & 0.16 & 0.16 & 0.16 & 0.16 \\
\hline Kurtosis & -0.38 & 0.19 & 6.87 & 0.07 \\
\hline Std. Error of Kurtosis & 0.32 & 0.32 & 0.32 & 0.32 \\
\hline
\end{tabular}

Source: own study

The Kruskal-Wallis analysis was to determine if there were any differences between employees' use of flexible work arrangement types (flexible work schedule and telecommuting) and in the means of employees' work-family conflict, family-work conflict, and the organizational outcomes of job performance and organizational commitment. The data was measured on Likert scales for dependent variables, with three levels of flexible work arrangements coded as dummy variables (flexible work schedule, telecommuting, and utilization of both options) based on Kruskal-Wall analyses (Field, 2013). The SPSS labels the KruskalWallis test as chi-square $\left(\mathrm{X}^{2}\right)$ measurement and uses "Asympt. Sig." as to whether significant or not significant (Field, 2013) indicated on the evaluation of findings.

The Kruskal-Wallis non-parametric analysis produced no statistically significant differences between employees' use of flexible work arrangement types (flexible work schedules and telecommuting) independent variables and dependent variables (work-family conflict, family-work conflict, job performance, and organizational commitment) or P>.05 (Table 8). However, the P-value was within the margin of error or rounding differences $(\mathrm{P}=.057)$ in support or similar to ANCOVA result for a family-work conflict as the dependent variable. Because there were no statistically significant relationship/differences based on KruskalWallis analyses, the post hoc/pairwise comparison tests could not be produced. The post hoc result would have revealed the flexible work arrangement group/s if there was a statistically significant difference or relationship. However, the rankings show some differences in the use of flexible work arrangements (table 7) to confirm to ANCOVA result.

Table 6: Ranks (Family-work conflict)

\begin{tabular}{l|l|c|}
\hline \multicolumn{1}{|c|}{ Flexible work arrangements } & N & Mean rank \\
\hline Flexible schedule & 97 & 127.12 \\
\hline Telecommuting & 37 & 95.8 \\
\hline
\end{tabular}




\begin{tabular}{l|l|c|}
\hline Flexible schedule \& Telecommuting & 103 & 119.69 \\
\hline Total & 237 & \\
\hline
\end{tabular}

Source: own study

Table 7. Kruskal-Wallis $\mathrm{H}$ outcome variable statistic tests

\begin{tabular}{l|c|c|c|c}
\hline \multicolumn{1}{c|}{ Category } & $\begin{array}{c}\text { Work-family } \\
\text { conflict }\end{array}$ & $\begin{array}{c}\text { Family-work } \\
\text { conflict }\end{array}$ & $\begin{array}{c}\text { Job } \\
\text { performance }\end{array}$ & $\begin{array}{c}\text { Organizational } \\
\text { commitment }\end{array}$ \\
\hline Chi-square & 1.56 & 5.74 & 0.8 & 4.85 \\
\hline Asymp. Sig. & 0.46 & 0.06 & 0.67 & 0.08 \\
\hline \multicolumn{5}{c}{ Source: own study }
\end{tabular}

\section{Evaluation of Findings and Conclusion}

The ANCOVA parametric analysis result indicated significant relationships $(\mathrm{P}=.05)$ between flexible work and organizational commitment holding familywork conflict as a covariate (table 6). The post ad hoc revealed significant relationships $(\mathrm{P}=.05)$ when employees use both flexible work schedules and telecommuting holding family-work conflict as a covariate. However, no statistical evidence to support employees' use of flexible work schedules or telecommuting (table 6). Also, the ANCOVA parametric analysis results indicated no significant relationships between flexible work arrangement types (flexible work schedules and telecommuting) independent variables and dependent variables (job performance and organizational commitment) holding work-family conflict as a covariate or $P>.05$ (table 6).

Table 8. ANCOVA Test between Subjects (covariate)

\begin{tabular}{l|c|c}
\hline Dependent variable & $\begin{array}{c}\text { Work-family conflict } \\
\text { (covariate Sig.) }\end{array}$ & $\begin{array}{c}\text { Family-work conflict } \\
\text { (covariate Sig.) }\end{array}$ \\
\hline Job performance & 0.64 & 0.85 \\
\hline Organizational commitment & 0.07 & 0.05 \\
\hline
\end{tabular}

Source: own study

An examination of the relationship between flexible work arrangements, work-family conflict, organizational commitment, and job performance 
The Kruskal-Wallis non-parametric analysis produced no statistically significant differences between employees' use of flexible work arrangement types (flexible work schedules and telecommuting) independent variables and dependent variables (work-family conflict, family-work conflict, job performance, and organizational commitment) or $P>.05$ (Table 8). However, the P-value was within the margin of error or rounding differences $(\mathrm{P}=.057)$ in support or similar to ANCOVA result for the family-work conflict as the dependent variable. Because there were no statistically significant relationship/differences based on KruskalWallis analyses, the post hoc/pairwise comparison tests could not be produced. The post hoc result would have revealed the flexible work arrangement group/s if there was a statistically significant difference or relationship. However, the rankings show some differences in the use of flexible work arrangements (table 7) to confirm to ANCOVA result.

Based on the results of ANCOVA and Kruskal Wallis analyses, the whitecollar employees studied in this research established a significant relationship between the use of flexible work arrangements (the use of both flexible work schedules and telecommuting), organizational commitment outcome variable, and family-work conflict as a covariate. The ANCOVA result further showed that the independent use of either flexible work schedules or telecommuting had no value to employees when holding work-family conflict as a covariate and job performance and organizational commitment as dependent variables. The results confirmed that organizational available resources such as employees' control of their schedule and telecommuting had a significant effect on the management of family role conflict. Management together with Human Resource should evaluate the multiple uses of various types of flexible work arrangements to improve employees' organizational commitment.

The findings of flexible work arrangements (flexible work schedule and telecommuting) and work-family conflict, family-work conflict, and organizational conflict may suggest blurred or about $51 \%$ of employees could be working long hours by transferring non-work time and difficult to determine the differences between work and family roles (SHRH, 2016). Also, the respondents having utilized flexible work arrangements regularly may view the benefits as a normal business practice or a right which may not affect. Future research should replicate this study to include flexible work arrangement users vs. non-flexible work arrangement employees. Also, extending this research beyond the service sector and other States and countries could be valuable to confirm these results. Also, a similar study is needed to investigate employees' perceptions if the flexible work arrangement 
options were reversed in their organizations. Lastly, a longitudinal study incorporating many variables would be worthwhile to determine causation and further analyze the effect of the demographic composition.

\section{Summary}

An examination of the relationship between flexible work arrangements, work-family conflict, organizational commitment, and job performance

Many employees are often faced with an inter-role conflict between work and that of a family in the U.S. However, business leaders and Human Resource Management (HRM) may not recognize the problem affecting white-collar employees. The purpose of this non-experimental quantitative study was to determine whether or not a relationship existed between employees' use of flexible working arrangements as predictor variables (such as flexible work schedules and telecommuting) and work-family conflict and family-work conflict as covariate variables, and organizational outcomes (such as organizational commitment and job performance outcome variables). The selfreported survey data included 237 employees who have utilized flexible work arrangements in service organizations in the state of Texas. The inconclusive ANCOVA parametric data assumption resulted in further employ Kruskal-Wallis statistical analysis with less restrictive normality assumption The ANCOVA and Kruskal-Wallis analyses tests revealed a statistically significant result for employees' use of flexible work options (a combination of flexible work schedules and telecommuting) to alleviate familywork conflict. The use of a single option (flexible work schedules or telecommuting) was statistically insignificant to employees. Despite the rigorous study, limitations are inevitable particularly for self-reported data and non-experimental study. The difficulty to determine the participants' honesty unintentional misrepresentations reflected in the validity of the study (Hunter, 2012; Matsui et al., 2005). Nevertheless, the study provided insight information to organizational management not to overlook the use of flexible work arrangement practices to mitigate employees' family-work conflict (Gözükara \& Çolakoğlu, 2015) to achieve organizational outcomes. Future researchers should replicate 
this study to include flexible work arrangement users vs. nonflexible work arrangement employees in other states, regions, and industries.

Keywords: Flexible work arrangements, flexible work schedules, job performance, organizational commitment, telecommute, work-family conflict.

\section{Streszczenie}

Badanie związku między elastycznymi ustaleniami dotyczącymi pracy, konfliktem między rodziną a pracą, zaangażowaniem organizacyjnym i wydajnością pracy

Wielu pracowników w USA często zmaga się z wewnętrznym konfliktem roli między pracą a rodziną. Liderzy biznesu i zarządzanie zasobami ludzkimi (HRM) mogą jednak nie rozpoznać problemu dotykającego pracowników umysłowych. Celem tego nie eksperymentalnego badania ilościowego było ustalenie, czy istniał związek między korzystaniem przez pracowników z elastycznych warunków pracy jako zmiennych predykcyjnych (takich jak elastyczne harmonogramy pracy i telepraca), a konfliktem na linii praca - rodzina oraz konfliktem na linii rodzina - praca jako zmienne towarzyszące i wyniki organizacyjne (takie jak zmienne dotyczące zaangażowania organizacyjnego i wyników pracy). Dane $\mathrm{z}$ ankiety własnej objęły 237 pracowników, którzy skorzystali z elastycznych warunków pracy $\mathrm{w}$ organizacjach usługowych $\mathrm{w}$ stanie Teksas. Niejednoznaczne założenie danych parametrycznych ANCOVA spowodowało dalsze zastosowanie analizy statystycznej KruskalWallis z mniej restrykcyjnym założeniem normalności. Analizy ANCOVA i Kruskal-Wallis wykazały statystycznie istotny wynik $\mathrm{w}$ zakresie korzystania przez pracowników z elastycznych opcji pracy (połączenie elastycznych harmonogramów pracy i telepracy ) w celu złagodzenia konfliktu na linii rodzina - praca. Zastosowanie jednej opcji (elastyczne harmonogramy pracy lub telepraca) było statystycznie nieistotne dla pracowników. Pomimo rygorystycznych badań ograniczenia są nieuniknione, szczególnie $\mathrm{w}$ przypadku danych własnych i badań nieeksperymentalnych. Trudność $\mathrm{w}$ ustaleniu uczciwości uczestników, niezamierzone wprowadzenie $\mathrm{w}$ błąd odzwierciedlone zostało $\mathrm{w}$ zasadności 
badania (Hunter, 2012; Matsui i in., 2005). Niemniej jednak badanie dostarczyło zarządowi organizacji dogłębnej informacji o nieprzeoczeniu zastosowania elastycznych praktyk w zakresie organizacji pracy $\mathrm{w}$ celu złagodzenia konfliktu między rodziną a pracą pracowników (Gözükara i Çolakoğlu, 2015) w celu osiągnięcia wyników organizacyjnych. Przyszli badacze powinni powtórzyć to badanie, aby uwzględnić użytkowników elastycznych organizacji pracy $\mathrm{w}$ porównaniu $\mathrm{z}$ nieelastycznymi pracownikami organizacji pracy $\mathrm{w}$ innych stanach, regionach i branżach.

\section{Słowa}

kluczowe: elastyczne warunki pracy, elastyczne harmonogramy pracy, wydajność pracy, zaangażowanie organizacyjne, telepraca, konflikt praca-rodzina.

\section{References}

1. Allen, T. D., Johnson, R. C., Kiburz, K. M., \& Shockley, K. M. (2013). Workfamily conflict and flexible work arrangements: Deconstructing flexibility. Personnel Psychology, 66, 345-376. DOI:10.1111/perps.12012.

2. American Psychological Association. (2011). Stress in the Workplace: Survey Summary. Retrieved from https://www.google.com/?gws_rd=ss 1\#q=American+Psychological+Association+study+2011.

3. Atkinson, C., \& Hall, L. (2011). Flexible working and happiness in the NHS. Employee Relations, 33, 88-105. DOI:10.1108/01425451111096659.

4. Bal, P. M., De Jong, S., Jansen, P. G. W., \& Bakker, A. B. (2012). Motivating employees to work beyond retirement: A multi-level study of the role of I-deals and unit climate. Journal of Management Studies, 49, 306-332.

5. Bhave, D., Kramer, A., \& Glomb, T. (2013). Pay satisfaction and workfamily conflict across time. Journal of Organizational Behavior, 34, 698-713.

6. Blazovich, J. L., Smith, K. T., \& Smith, M. (2013). Employee-friendly companies and work-life balance: Is there an impact on financial performance and risk level? Journal of Organizational Culture, Communications, and Conflict. Retrieved from http://papers.ssrn.com/ sol3/Delivery.cfm/SSRN_ID2396084_code242236.pdf?abstractid=239608 $4 \&$ mirid $=1 \&$ type $=2$.

7. Brown, L. M. (2010). The relationship between motherhood and professional advancement. Employee Relations, 32, 470-494. http://dx.doi. org/10.1108/01425451011061649.

8. Buonocore, F., Russo, M., \& Ferrara, M. (2015). Work-family conflict and job insecurity: are workers from different generations experiencing true differences? Community, Work \& Family, 18, 299. http://dx.doi. org/10.1080/13668803.2014.981504. 
9. Burke, R. J., Koyuncu, M., \& Fiksenb, L. (2013). Antecedents and consequences of work-family conflict and family-work conflict among frontline employees in Turkish hotels. IUP Journal of Management Research, 12(4), 39-55.

10. Cairns, T. D. (2013). What will tip the scales for flexible work arrangementsmotivation or collaboration? Employment Relations Today (Wiley), 40(2), 2933. http:/ / dx.doi.org/10.1002/ert.21408.

11. Carlson, D., Hunter, E., Ferguson, M., \& Whitten, D. (2014). Work-family enrichment and satisfaction: mediating processes and relative impact of originating and receiving domains. Journal of Management, 40(3), 845-865. DOI:10.1037/t03592-000.

12. Caykoylu, S., Egri, C. P., Havlovic, S., \& Bradley, C. (2011). Key organizational commitment antecedents for nurses, paramedical professionals, and non-clinical staff. Journal of Health Organization and Management, 25, 7-33. http://dx.doi .org/10.1108/14777261111116806.

13. Chernyak-Hai, L., \& Tziner, A. (2015). The I believe and then I invest in work-family balance: The indirect influences of personal values and work engagement via perceived organizational climate and workplace burnout. Revista De Psicología Del Trabajo Y De Las Organizaciones, DOI:10.1016/j. rpto.2015.11.004.

14. Cheung, M., \& Wong, C. (2013). Work-family/family-work conflict: the moderating roles of gender and spousal working status. Asia Pacific Journal of Human Resources, 51, 330-346. http:/ / dx.doi.org/10.1111/j.17447941.2013.00064.x.

15. Coenen, M., \& Kok, R. W. (2014). Workplace flexibility and new product development performance: The role of telework and flexible work schedules. European Management Journal, 32, 564-576. http://dx.doi. org/10.1016/j.emj.2013.12.003.

16. De Janasz, S., Behson, S. J., Jonsen, K., \& Lankau, M. J. (2013). Dual sources of support for dual roles: How mentoring and work-family culture influence work-family conflict and job attitudes. International Journal of Human Resource Management, 24, 1435-1453. http://dx.doi.org/10.1080/ 09585192.2012.709187.

17. De Sivatte, I., \& Guadamillas, F. (2013). Antecedents and outcomes of implementing flexibility policies in organizations. International Journal of Human Resource Management, 24, 1327-1345. http://dx.doi.org/10.1080/0 9585192.2011.561225.

18. Duncan, K. A., \& Pettigrew, R. N. (2012). The effect of work arrangements on the perception of work-family balance. Community, Work \& Family, 15, 403-423. http://dx.doi.org/10.1080/13668803.2012.724832.

19. Field, A. (2013). Discovering statistics using IBM SPSS statistics. CA: Sage. Publications, Inc. 
20. Fiksenbaum, L.M. (2013).Supportive work-family environments: Implications for work-family conflict and well-being. The International Journal of Human Resource Management, 25, 653-672. DOI:10.1080/09585192.2013 .796314.

21. Galea, C., Houkes, I., \& De Rijk, A. (2014). An insider's point of view: How a system of flexible working hours helps employees to strike a proper balance between work and personal life. International Journal of Human Resource Management, 25, 1090-1111. DOI: 10.1080/09585192.2013.816862.

22. Galinsky, E., \& Matos, K. (2011). The future of work-life fit. Organizational Dynamics, 40, 267-280. Doi:10.1016/j.orgdyn.2011.07.004.

23. Goh, Z., Ilies, R., \& Wilson, K. S. (2015). Supportive supervisors improve employees' daily lives: The role supervisors play in the impact of daily workload on life satisfaction via a work-family conflict. Journal of Vocational Behavior, 8965-73. DOI: 10.1016/j.jvb.2015.04.009.

24. Gözükara, İ., \& Çolakoğlu, N. (2015). The impact of manager support and work-family conflict on job satisfaction. Business Management Dynamics, $5(6), 13-25$.

25. Greene, W. H. (2012). Econometric analysis (7th ed.). Upper Saddle River, NJ: Prentice-Hall.

26. Henly, J. R., \& Lambert, S. J. (2014). Unpredictable work timing in retail jobs: Implications for employee work-life conflict. Industrial and Labor Relations Review, 67, 986-1016. http://dx.doi.org/10.1177/0019793914537458.

27. Kossek, E. E., Baltes, B. B., \& Matthews, R. A. (2011). How work-family research can finally have an impact on organizations. Industrial and Organizational Psychology: Perspectives on Science and Practice, 4, 352-359.

28. Maharshi, N., \& Chaturvedi, R. (2015). A study of factors-affecting the work-life balance of women employees working in public and private sector banks of Rajastan. Asia Pacific Journal of Management and Entrepreneurship Research, 4, 89-107. Retrieved from http://www.apjmer. org/articles/mgt144.pdf.

29. Matthews, R. A., Kath, L. M., \& Barnes-Farrell, J. L. (2010). A short, valid, predictive measure of work-family conflict: Item selection and scale validation. Journal of Occupational Health Psychology, 15(1), 75-90. DOI: 10.1037/a0017443.

30. Minnotte, K. L. (2012). Family structure, gender, and the work-family interface: Work-to-family conflict among single and partnered parents. Journal of Family and Economic Issues, 33(1), 95-107. http://dx.doi. org/10.1007/s10834-011-9261-4.

31. Mowday, R. T., Steers, R. M., \& Porter, L. W. (1979). The measurement of organizational commitment. Journal of Vocational Behavior, 14, 224-247. http:/ / dx.doi.org/10.1016/0001-871 (79)90072-1.

32. Munsch, C., Ridgeway, C., \& Williams, J. (2014). Pluralistic ignorance and the flexibility bias: understanding and mitigating flextime and flexplace bias at work. Work and Occupations, 41(1), 40-62. 
33. Parker, K. \& Wang, W. (2013). Modern Parenthood: Roles of moms and dads converge as they balance work and family. Retrieved from Pew Research website: http://www.pewsocialtrends.org/files/2013/03/ FINAL_modern_parenthood_03-2013.pdf.

34. Shannon-Missal, L (2014). Vast majority of Americans favor flexible workplace policies. Retrieved from Nielsen \& the Harris: http://www. harrisinteractive.com/vault/Harris \% 20Poll \% 2059\%20-\%20Working $\% 20$ Families_06.19.2014.pdf.

35. Society for Human Resource Management, (2013, 2016). Workplace flexibility in the 21st century: Meeting the needs of the changing workforce. Retrieved from http:/ / secure-us.imrworldwide.com/cgi-bin/ $\mathrm{b}$ ?ci=us-shrm\&cg=pdftracking\&tu=http:/ / www.shrm.org/Research/ SurveyFindings/Articles/Documents/09-0464_Workplace_Flexibility_ Survey_Report_inside_FINALonline.pdf.

36. Sturman, M. C., \& Walsh, K. (2014). Strengthening the employment relationship: The effects of work-hours fit on key employee attitudes. Journal of Organizational Behavior, 35(6), 762-784. DOI:10.1002/job.1925.

37. Swanberg, J. E., McKechnie, S. P., Ojha M. U., \& James, J. B. (2011). Schedule control, supervisor support, and work engagement: A winning combination for workers in hourly jobs? Journal of Vocational Behavior, 79, 613-624. http://dx.doi.org/10 .1016/j.jvb.2011.04.012.

38. Sweet, S., Pitt-Catsouphes, M., Besen, E., \& Golden, L. (2014). Explaining organizational variation in flexible work arrangements: Why the pattern and scale of availability matter. Community, Work \& Family, 17, 115-141. http://dx.doi.org /10.1080/13668803.2014.887553.

39. Thompson, C. A., Beauvais, L. L., \& Lyness, K. S. (1999). When workfamily benefits are not enough: The influence of work-family culture on benefit utilization, organizational attachment, and work-family conflict. Journal of Vocational Behavior, 54392-415. DOI:10.1006/jvbe.1998.1681.

40. Wells-Lepley, M., Thelen, L. A., \& Swanberg, J. (2015). Supervisors' use of flexibility as a strategic management tool: Prevalence and predictors. The Psychologist-Manager Journal, 18(1), 31-53. http:// dx.doi.org/10.1037/ mgr0000027.

41. Wickramasinghe, V. (2012). Supervisor support as a moderator between work schedule flexibility and job stress. International Journal of Workplace Health Management, 5, 44-55. http://dx.doi. org/10.1108/17538351211215384.

42. World Bank, (n.d). Section 9: Growth of the service sector. Retrieved from http://www.worldbank.org/depweb/beyond/beyondco/beg_09.pdf.

43. Yang, J., Mossholder, K. W., \& Peng, T. (2009). Supervisory procedural justice effects: The mediating roles of cognitive and affective trust. The Leadership Quarterly, 20143-154. DOI:10.1016/j.leaqua.2009.01.009. 